UDC 621.382

\title{
THROUGHPUT INCREASE IN THE OFFICE LI-FI SYSTEM
}

\author{
Oleksandr I. Romanov, Gleb O. Miklaiv \\ Institute of Telecommunication Systems \\ Igor Sikorsky Kyiv Polytechnic Institute, Kyiv, Ukraine
}

Background. Wi-Fi has many disadvantages, such as how the maximum bandwidth is limited by the frequency of the range. The work uses Li-Fi technology, which uses visible light for data transmission. The frequency range of Li-Fi is 1000 times greater than the entire radio range. Feedback is used to increase the throughput. But the feedback decreases the bandwidth of the downstream signal.

Objective. The purpose of the paper is to analyse what parameters are advisable to change to increase the throughput of the Li-Fi system.

Methods. Study of the simulated dependence of the optimal interval change for using the feedback, and using this interval plot the dependence of the throughput on the change in the parameters of the Li-Fi system with a mobile user.

Results. With an increase in the area of the photodiode and its refractive index, the throughput increases. As the receiver speed increases, the throughput decreases slightly $<0.1 \%$. Reducing the angle of the photodiode field of view and the halfangle of radiation significantly increases the throughput (by 50\%) only when decreasing to small angles $\left(<10^{\circ}\right.$ ).

Conclusions. It is advisable to make photodiode from a material with a high refractive index, with a big area. Since mobile devices are often used in the office Li-Fi network, it is not advisable to reduce the receiver's viewing angle, as well as to reduce the half-angle of radiation. It may also be beneficial to give mobile users more download throughput than upload throughput.

Keywords: Light-Fidelity (Li-Fi); throughput; feedback; refresh interval; VLC.

\section{INTRODUCTION}

The amount of traffic used in the world is growing every year. And, Wi-Fi is on the edge of its capabilities[1]. Therefore, a variant for solving this problem was used, a transition to another part of the range of the electromagnetic spectrum - the visible light, namely the Li-Fi technology. Li-Fi technology was proposed by Harald Haas in 2011 [2].

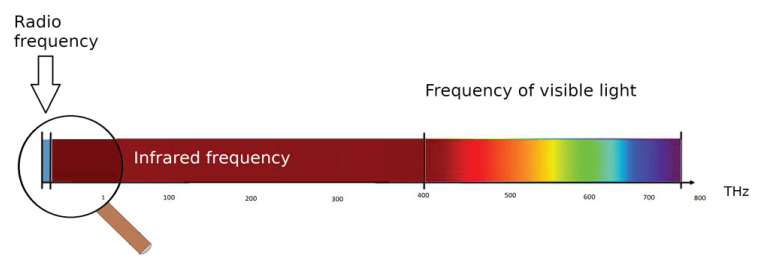

Fig. 1. Part of the electromagnetic spectrum on a linear scale

Unlike Wi-Fi, Li-Fi has such advantages:

- The frequency range is 1000 times greater over the entire radio spectrum. [2]

- Suitable for use where radio devices are restricted by the interference they generate, such as hospitals, airplanes, nuclear power plants, etc.

- LED lighting is a ready-made infrastructure for building a Li-Fi network [3].

- Li-Fi cannot be intercepted outside the room.
- Li-Fi is safe for health because it uses the light that is used in LED lamps.[4,5,6] LED lights switch so quickly that they don't cause epilepsy.

- Manufacturing $\mathrm{Li}-\mathrm{Fi}$ components is environmentally friendly as it complies with the Kyoto Protocol [7].

O-OFDM manipulation is often used in Li-Fi. For more efficient use, periodically send information about the position of the signal receiver to the transmitter. Optimization is needed when changing location or tilt angles. This article analyses the change in position, that is, the radial movement from the point of perpendicular incidence of the signal to the edge of the signal receiving.

\section{Modelling}

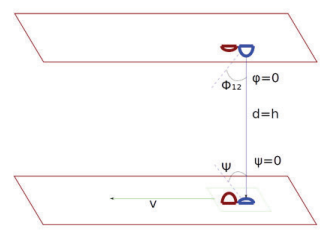

a)

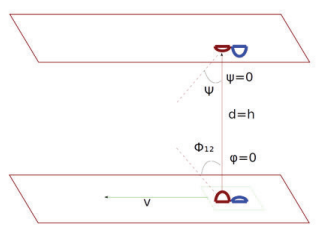

b)
Fig. 2. Fixed transmitter and receiver. a) downlink from transmitter to receiver. b) uplink to transmitter from receiver 


\section{A. Fixed transmitter and receiver. The receiver is perpendicular to the transmitter}

The simplest model was developed from the beginning. In it, the angles of receiving and transmission are equal to zero, the receiver is located perpendicular to the transmitter. Also this model is unidirectional. This model is simple, but it is used with one stationary source and stationary receiver. It is shown in Fig.2 a). Further, by analogy, a model has been developed that includes data transfer from the terminal to the access point. This is called feedback. It is shown in Fig.2 b). For feedback, not only visible light can be used, but also infrared signal or even radio signal, for example, Wi-Fi, especially when you do not need such high speeds for uploading as for downloading. Combining Fig.1 a) and Fig.1 b), we get the simplest bidirectional Li-Fi model. This model is fixed. In it, nothing changes over time and there is no need to request data about the user's position. In the model, the angles of receiving and transmission are equal to zero.

\section{B. Fixed transmitter and receiver. The receiver is not perpendicular to the transmitter}

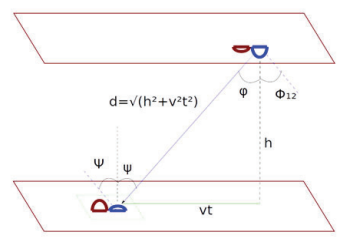

a)

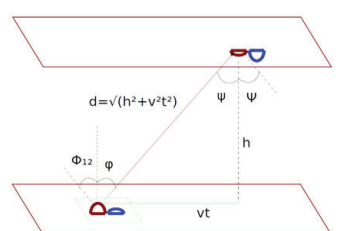

b)
Fig. 3. A radially displaced source from a perpendicular location to the source, which is shown in Fig. 2. The movement took place at a constant speed v, in time t. a) downlink b) uplink.

After the end of the movement, the system will again be fixed, and again there will be no need to request information about the position of the terminal. In this case, the energy received by the receiver from the LED is considered the following odds $[8,9]$ :

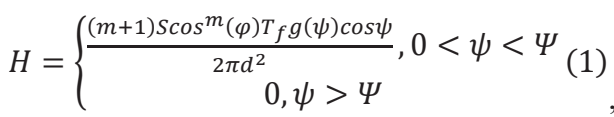

where $m=-1 / \log _{2}\left(\cos \quad \Phi_{12}\right)$ and $\mathrm{g}(\psi)=\mathrm{n}^{2} / \sin ^{2} \quad \Psi$ $\mathrm{d}=\sqrt{ }\left(\mathrm{h}^{2}+\mathrm{v}^{2} \mathrm{t}^{2}\right)$.

$\mathrm{S}$ is the area of the receiver, $\varphi$ is the radiation angle, $\psi$ is the angle of incidence, $\Phi_{12}$ is the half-angle of radiation, $\Psi$ is the boundary angle of reception, Tf is the gain of the optical filter, $d$ is the distance between the emitter and the receiver, $\mathrm{n}$ is the emitter rejection index. $\mathrm{m}$ is the Lambert exponent, $\mathrm{g}(\psi)$ is the gain of the optical concentrator. $h$ is the height between transmitter and receiver. vt is the horizontal component of the distance, $\mathrm{v}$ is the speed of the terminal, $\mathrm{t}$ is the time of movement

\section{Not fixed receiver. Receiver moves radially from center}

The next step is to take into account the movement. It is between Fig.1 and Fig.2. In this case, it is optimal to periodically request position data from the user terminal. This paper addresses this situation.

\section{Calculing}

\section{A. Mathematical apparatus}

To calculate the throughput, the formula is used:

$\mathrm{T}=\omega_{\mathrm{up}} \mathrm{R}_{\mathrm{up}}+\omega_{\mathrm{dw}} \mathrm{R}_{\mathrm{dw}}$, (2)

where $\omega_{\text {up }}$ and $\omega_{\text {dw }}$ are weight coefficients of uplink and downlink, respectively. $\omega_{\text {up }}+\omega_{\mathrm{dw}}=1, \omega_{\text {up }}$ and $\omega_{\mathrm{dw}}>0$.

$\mathrm{R}_{\text {up }}$ and $\mathrm{R}_{\mathrm{dw}}$ are upload and download throughput respectively. They are considered in the following formulae[10]:

$$
\begin{aligned}
R_{d w}= & \frac{B_{d w k_{\min }}}{K} \cdot\left(\log _{2}\left(\frac{G \cdot \exp \left(-2 \pi\left(k_{\min }+1\right) B_{d} / K \omega_{0}\right)}{\left(h^{2}+v^{2} t_{u}^{2}\right)^{m+3}}\right)\right) \\
& +\frac{2(m+3)}{\ln (2)}-\frac{2 h(m+3)}{v t_{u}} \tan ^{-1}\left(\frac{v t_{u}}{h}\right)
\end{aligned}
$$

where $\mathrm{B}_{\mathrm{dw}}$ is the thickness of the descending channels; $\mathrm{K}$ is the number of subcarriers; $\mathrm{k}_{\min }$ is the number of subcarriers for one terminal; tu is update interval; $\omega_{0}$ is the fitted coefficient

$$
\begin{aligned}
R_{u p} & =\left(1-\frac{t_{f b}}{t_{u}}\right) \frac{B_{d w}}{K} \cdot\left(\log _{2}\left(\frac{G_{u}}{\left(h^{2}+v^{2} t^{2}\right)^{m+3}}\right)\right) \\
{[10] . \quad+} & +\frac{2(m+3)}{\ln (2)}-\frac{2 h(m+3)}{v t_{u}} \tan ^{-1}\left(\frac{v t_{u}}{h}\right)
\end{aligned}
$$

where $B_{d w}$ is the bandwidth of the uplink channels; $t_{\mathrm{fb}}$ is time for feedback.

$$
\begin{gathered}
G_{0}=\frac{(m+1) S g_{f} n^{2} h^{m+1}}{2 \pi \sin ^{2} \Psi}(5) \\
G=\frac{K G_{0}^{2} P_{P D}^{2} P_{d w}^{2}}{(K-2) \eta^{2} N_{0} B_{d w}}(6),
\end{gathered}
$$


where $\mathrm{P}_{\mathrm{PD}}$ is the transmitted optical power. $\mathrm{N}_{0}$ is noise power spectral density; $\mathrm{P}_{\mathrm{dw}}$ is transmitted downlink optical power; $\eta$ is the conversion factor, and $\eta>3$ to ensure less than $1 \%$ of signal being clipped. $G_{u}=\frac{G_{0}^{2} P_{P D}^{2} P_{u p}^{2}}{\eta^{2} N_{0} B_{u p}}(7)$,

where $\mathrm{P}_{\mathrm{up}}$ is transmitted uplink optical power. $k_{\min } \simeq \frac{K T_{r e q}}{B_{d w} \log _{2}\left(G / h^{2 m+6}\right)}(8)$,

where $\mathrm{T}_{\text {req }}$ is request data rate. $[10]^{t_{u, o p t}} \simeq\left(\frac{\frac{3 \ln (2)}{2 m+6} \omega_{u p} h^{2} t_{f b} B_{u p} \log _{2}\left(\frac{G u}{h^{2 m+6}}\right)}{\omega_{d w} N \frac{T_{r e q}}{\log _{2}\left(G / h^{2 m+6}\right)}+\omega_{u p} B_{u p}}\right)^{\frac{1}{3}} v^{\frac{-2}{3}}(9)$

The resulting interval in (8) is substituted in (3) and (4), then substitute in (2).

\section{B. When is valid}

When SNR at the transmitter and the receiver are $>10$. SNR at the transmitter is given as [10]:

$\gamma_{u}=\frac{R_{p d}^{2} P_{u p}^{2} H^{2}}{\eta^{2} N_{0} B_{u p}}(10)$

Where $R_{p d}$ is photodiode responsivity. SNR at the receiver is given as:

$\gamma_{j, k}=\frac{\operatorname{Gexp}\left(-4 \pi k B_{d w} / K \omega_{0}\right)}{\left(h^{2}+v^{2} t^{2}\right)^{m+3}}(11)$

where $\mathrm{k}$ is $\mathrm{k}$-th subcarriers.

\section{Graphing}

\section{A. Used values}

Table 1. Parameters

\begin{tabular}{|l|l|l|}
\hline Parameter & $\begin{array}{l}\text { Symbo } \\
\mathbf{l}\end{array}$ & Value \\
\hline Area of photodiohe & $\mathrm{S}$ & $0.0001 \mathrm{~m}^{2}$ \\
\hline Gain of optical filter & $\mathrm{T}_{\mathrm{f}}$ & 1 \\
\hline Half-intensity radiation angle & $\Phi_{12}$ & $\pi / 3$ \\
\hline Receiver field of view & $\Psi$ & $\pi / 2$ \\
\hline
\end{tabular}

\begin{tabular}{|c|c|c|}
\hline Refractive index & $\mathrm{n}$ & 1.5 \\
\hline Number of subcarriers & K & 2048 \\
\hline $\begin{array}{lll}\text { Downlink frequency } & \text { reuse } \\
\text { bandwidth } & & \\
\end{array}$ & $\mathrm{B}_{\mathrm{dw}}$ & $10 \mathrm{MHz}$ \\
\hline $\begin{array}{l}\text { Transmitted downlink optical } \\
\text { power }\end{array}$ & $\mathrm{P}_{\mathrm{dw}}$ & $8 \mathrm{~W}$ \\
\hline $\begin{array}{l}\text { Uplink frequency reuse } \\
\text { bandwidth }\end{array}$ & $\mathrm{B}_{\mathrm{up}}$ & $5 \mathrm{MHz}$ \\
\hline $\begin{array}{l}\text { Transmitted uplink optical } \\
\text { power }\end{array}$ & $P_{\text {up }}$ & $0.1 \mathrm{~W}$ \\
\hline Weight coefficient of downlink & $\omega_{\mathrm{dw}}$ & 0.75 \\
\hline Weight coefficient of uplink & $\omega_{\text {up }}$ & 0.25 \\
\hline Fitted coefficietn & $\omega_{0}$ & $\begin{array}{l}45.3 \\
\mathrm{Mrad} / \mathrm{s}\end{array}$ \\
\hline Noise power spectral density & $\mathrm{N}_{0}$ & $10^{-21} \mathrm{~A}^{2} / \mathrm{Hz}$ \\
\hline Velocity & $\mathrm{V}$ & $1.5 \mathrm{~m} / \mathrm{s}$ \\
\hline Conversion factor & $\eta$ & 3 \\
\hline Request data rate & $\mathrm{R}_{\text {req }}$ & $30 \mathrm{Mbps}$ \\
\hline Feedback time & $t_{f b}$ & $1 \mathrm{~ms}$ \\
\hline Number of terminals & $\mathrm{N}$ & 4 \\
\hline Photodiode responsivity & $\mathrm{R}_{\mathrm{PD}}$ & $1 \mathrm{~A} / \mathrm{W}$ \\
\hline
\end{tabular}

Photodiodes have an area on which, after the signal falls, it is received and processed. The larger this area, the more likely it is to receive and process the signal, and the higher the bandwidth. The area of this area is indicated by the letter $\mathrm{A}$.

Optical filters suppress that part of the electromagnetic spectrum that is not used by the access point, but can be received by the photodiode. This work does not use a filter, so the factor is 1 .

The larger the reception angle, the more information can be received. But in addition to useful information, there may be noise. Therefore, with a fixed access point and a photodiode, as in Fig. 1, if the receiver did not move, then this angle should be minimized, and with movable, and in this study, this is exactly what is being investigated, then decreasing the angle will increase the throughput, when located close to perpendicular, but at large reception angles $\psi$, the signal becomes completely lost.

The situation is similar to the half angle of radiation $\Phi_{12}$, the larger the angle, the more noise, but the smaller the angle, the smaller the reception area.

A transparent material is needed for the light to pass to the photodiode. This material has a refractive index. 
The higher the refractive index, the more signal will get to the photosensitive area of the photodiode. The refractive index is denoted by $n$.

$\mathrm{K}$ number of signal subcarriers used for O-OFDM modulation

The signal has a frequency range of electromagnetic light. The larger the range, the more information can be conveyed. In the work referred to as $\mathrm{B}_{\mathrm{dw}}$ and $\mathrm{B}_{\mathrm{up}}$.

The signal has its own power, and the more power, the less information will be lost during reception due to noise. But increasing capacity increases energy consumption. The transmitter is always connected to the mains, so its power can be much higher than that of the receiver, which may not always be connected to the mains. Designated as $\mathrm{P}_{\mathrm{dw}}$ and $\mathrm{P}_{\text {up }}$ respectively.

The total bandwidth consists of the bandwidth for receiving and transmitting the signal. The ratios of the provided throughput of the download to the total, and of the upload to the total are designated as $\omega_{\mathrm{dw}}$ and $\omega_{\text {up }}$, respectively, with $\omega_{\mathrm{up}}+\omega_{\mathrm{dw}}=1$.

The frequency response is modelled as $\mathrm{H}=\exp (\omega /$ $\left.\omega_{0}\right)$, where $\omega_{0}$ is the fitted coefficient.

In addition to the desired signal, noise gets to the photodiode. We assume that our noise power density is No.

We think our receiver is moving. The movement occurs radially with a speed $\mathrm{v}$.

We have several users in our system. Therefore, we will assume that all users need to provide bandwidth in $\mathrm{R}_{\text {req. }}$.

The time period when the feedback information is transmitted is $\mathrm{t}_{\mathrm{fb}}$.

We have a multi-user network, the number of users is $\mathrm{N}$.

A signal arriving at the photodiode with power $\mathrm{P}$ will produce a current $\mathrm{I}=\mathrm{PR} P \mathrm{PD}$.

Table 2: Variables

\begin{tabular}{|l|l|l|l|}
\hline $\begin{array}{l}\text { Variable } \\
\text { symbol }\end{array}$ & $\begin{array}{l}\text { Minimal } \\
\text { value }\end{array}$ & $\begin{array}{l}\text { Maximum } \\
\text { value }\end{array}$ & Step \\
\hline $\mathrm{v}$ & $0.1 \mathrm{~m} / \mathrm{s}$ & $5 \mathrm{~m} / \mathrm{s}$ & $0.01 \mathrm{~m} / \mathrm{s}$ \\
\hline$\omega_{\mathrm{dw}}$ & 0 & 1 & 0.001 \\
\hline$\Psi$ & $0 \mathrm{rad}$ & $\pi / 2 \mathrm{rad}$ & $0.001 \mathrm{rad}$ \\
\hline$\Phi_{12}$ & $0 \mathrm{rad}$ & $\pi / 2 \mathrm{rad}$ & $0.001 \mathrm{rad}$ \\
\hline $\mathrm{S}$ & $3 \mathrm{~cm}^{2}$ & $0.3 \mathrm{~cm}^{2}$ & $0.01 \mathrm{~cm}^{2}$ \\
\hline $\mathrm{n}$ & 1 & 1.5 & 0.001 \\
\hline
\end{tabular}

\section{B. Results}

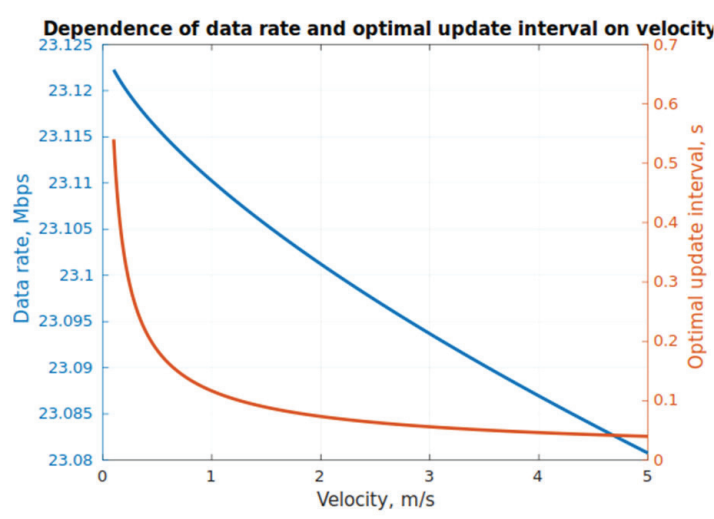

a)

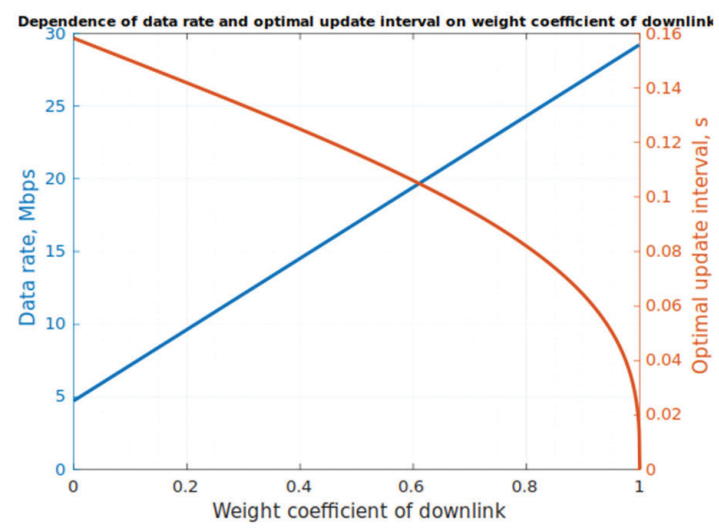

b)

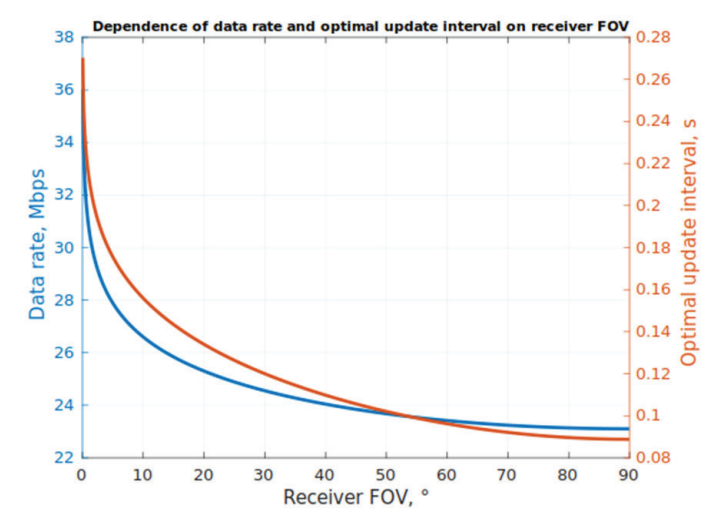

c) 


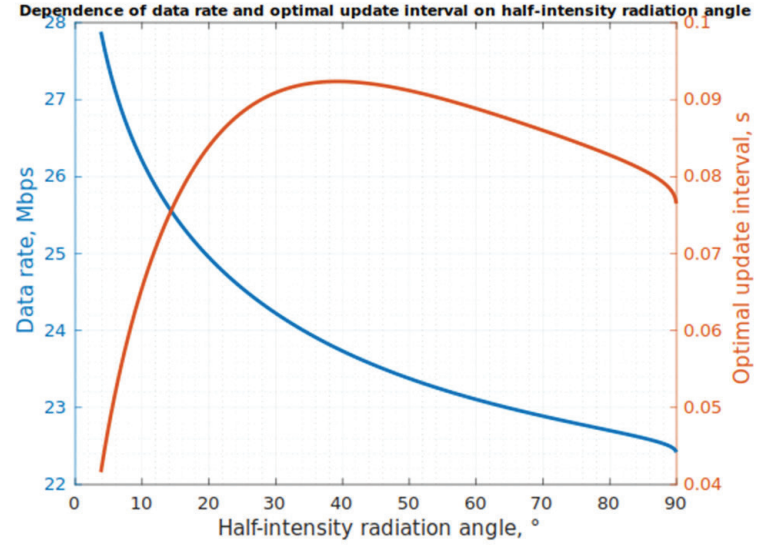

d)

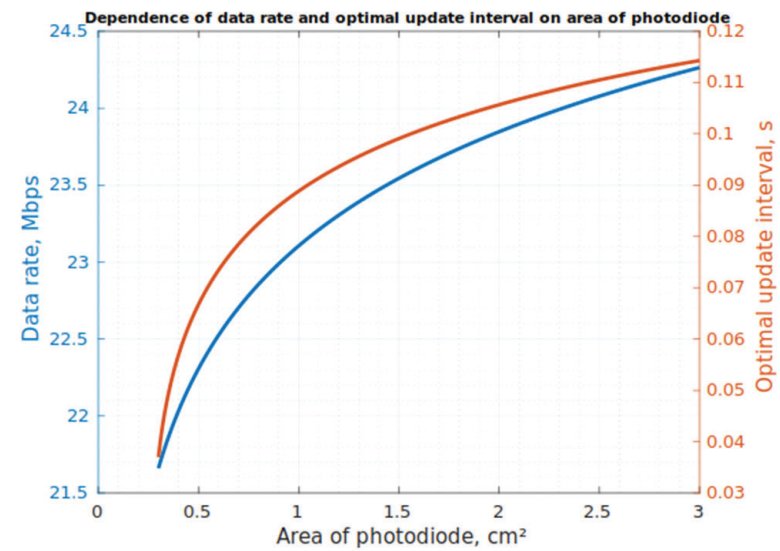

e)

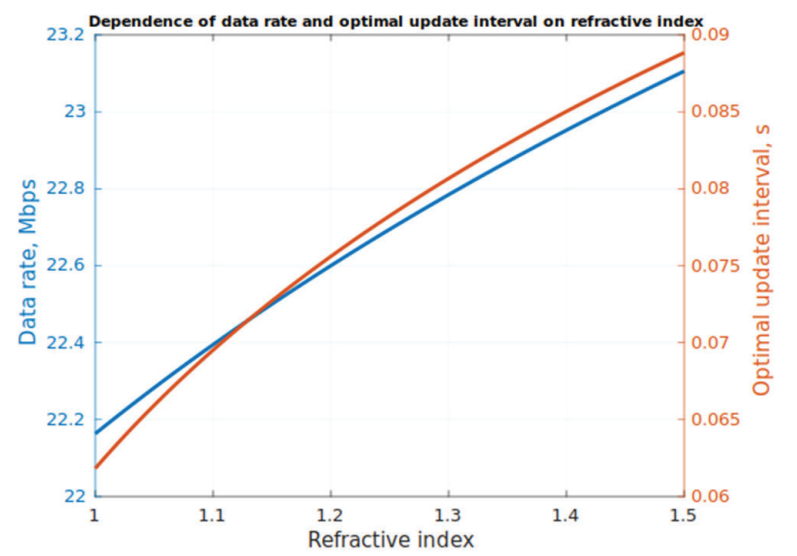

f)

Fig. 4. Dependence of data rate and optimal update interval on a) velocity b) weight coefficient of downlink c) receiver field of view d) half-intensity radiation angle e) area of photodiode f) refractive index

As can be seen in the plots, the throughput is not always inversely proportional to the optimal update interval. From Fig. 4, a, it can be seen that the throughput does not decrease with increasing speed, but the optimal update interval hyperbolically decreases. According to Fig. 4, b it is noticeable that when the user is only given the opportunity to download, then the requested speed is fully satisfied, the optimal update interval tends to zero. In the opposite extreme cases, when only the user is provided for uploading, then the bandwidth is 6 times less than the requested one. Fig.4, c shows that the plots are very similar, despite their inversely proportional dependence. When the field of viewing angle is small, then both dependent are large. Fig 4, d shows that the optimal update interval is maximum in the range from $30^{\circ}$ to $45^{\circ}$, and the bandwidth is monotonically decreasing. In Fig. 4 e), it can be seen that the optimal update interval is noticeably dependent on the area, and the throughput is not very strong dependence. Fig. 4, f a similar situation to Fig. 4, e.

\section{CONCLUSION}

Having analysed the dependencies, the following conclusions can be drawn.

Perhaps, when designing a network based on Li-Fi technology, it makes sense to provide users with unequal download and upload speed coefficients. First, users are more likely to download than upload. Second, mobile users are more likely to be unconnected to power sources, and increasing transmission power, while increasing bandwidth, increases power usage. Too large field of view and half-intensity radiation angle reduces the bandwidth, but not critical. It is better for mobile users to provide the maximum possible field of view and half-intensity radiation angle that provide full coverage. For example, a $90^{\circ}$ field of view has $20 \%$ less bandwidth, than a $10^{\circ}$ field of view. The refractive index, the area of the photodiode is not greatly affected. And at a walking speed from a stationary one, the throughput differs by only $0.1-0.2 \%$.

\section{REFERENCES}

1. Cisco Visual Networking Index: Global Mobile Data Traffic Forecast Update, 2016-2021 White Paper.

2. D.Tsonev, S.Videv, and H.Haas, "Towards a $100 \mathrm{~Gb} / \mathrm{s}$ visible light wireless access network", Optics Express, vol.23, no.2, pp.1627-1637, Jan.2015.

3. Oleksandr Romanov, Tho Dong and Mikola Nesterenko. The Possibilities for Deployment EcoFriendly Indoor Wireless Networks Based on LiFi Technology/ 8th International Conference on Applied Innovations in IT, (ICAIIT), March 2020.

4. CELMA, Optical safety of LED lighting

5. Pingree T.L., Dangers of Overexposure to ultraviolet, infrared and high-energy visible light 
6. HranilovicS. and KschischangF.R., Optical Intensity-Modulated Direct Detection Channels: Signal Space and Lattice Codes, Information Theory, IEEE Transactions Volume 49 Issue 6, pp. 1385 -1399, 285 2003.

7. Romanov O.I., Fediushyna D.M., Dong T.T. Model and method of Li-Fi network calculation with multipath light signals / 2018 International Conference on Information and Telecommunication Technologies and Radio Electronics, UkrMiCo 2018, 9047550/DOI: 10.1109/UkrMiCo 43733.2018.

8. Li Beam: Throughput-Optimal Cooperative Beamforming for Indoor Visible Light Networks
9. O.I. Romanov, Y. S. Hordashnyk, and T. T. Dong, "Method for calculating the energy loss of a light signal in a telecommunication Li-Fi system", International Conference on Information and Telecommunication Technologies and Radio Electronics (UkrMiCo), IEEE Conference Publications, pp.: 1-7, 2017;

10. On Throughput Maximization Based on Optimal Update Interval in LiFi Networks; Mohammad Dehghani Soltani, Majid Safari, and Harald Haas, LiFi R\&D Center, Institute for Digital Communications, University of Edinburgh, Edinburgh, EH9 3JL, UK.

\section{Романов О. І., Мікляєв. Г.О.}

Збільшення пропускної спроможності офісної Li-Fi системи

Проблематика. У Wi-Fi є багато недоліків, наприклад, як максимальна пропускна спроможність обмежена частотою діапазону. У роботі використано технологію Li-Fi, яка використовує видиме світло для передавання даних. Діапазон частот у Li-Fi більше у 1000 разів за увесь радіо діапазон. Для збільшення пропускної здатності використовують зворотній зв'язок. Але зворотній зв'язок зменшує пропускну здатність низхідного сигналу.

Мета дослідження. Проаналізувати, які параметри доцільно змінювати для збільшення пропускної здатності системи Li-Fi.

Методика реалізації. Дослідження змодельованої залежності зміни оптимального інтервалу використання зворотнього зв'язку, та використовуючи цей інтервал побудова залежності пропускної здатності від зміни параметрів системи Li-Fi з рухомим користувачем.

Результати дослідження. При збільшені площі фотодіода, чи його показника заломлення збільшується пропускна здатність. При збільшені швидкості приймача пропускна здатність спадає незначно, $<0.1 \%$. Зменшення кута поля зору фотодіода та половинного кута випромінення суттєво збільшує пропускну здатність (на 50\%) лише при зменшені до малих кутів $\left(<10^{\circ}\right)$.

Висновки. Доцільно фотодіод виготовляти 3 матеріалу з більшим показником заломлення, та не замалою площею. Оскільки в офісній мережі Li-Fi часто використовуються рухомі пристрої, то не є доцільним в них зменшувати кут видимості приймача, як і зменшувати половинний кут випромінення. Також може бути доцільним надавати більшу пропуснку здатність завантаження, ніж відвантаження.

Ключові слова: Light-Fidelity (Li-Fi); пропускна здатність; зворотній зв'язок; інтервал оновлення; VLC.

\section{Романов А. И., Микляев. Г.О.}

Увеличение пропускной способности офисной Li-Fi системы

Проблематика. Wi-Fi имеет много недостатков, например, как максимальная пропускная способность ограничена частотой диапазона. В работе использована технология Li-Fi, использующая видимый свет для передачи данных. Диапазон частот в Li-Fi больше в 1000 раз за весь радиодиапазон. Для увеличения пропускной способности используют обратную связь. Но обратная связь уменьшает пропускную способность нисходящего сигнала.

Цель исследования. Проанализировать, какие параметры целесообразно изменять для увеличения пропускной способности системы Li-Fi.

Методика реализации. Исследование смоделированной зависимости изменения оптимального интервала использования обратной связи, и используя этот интервал построение зависимости пропускной способности от изменения параметров системы Li-Fi с подвижным пользователем.

Результаты исследования. При увеличении площади фотодиода или его показателя преломления увеличивается пропускная способность. При увеличении скорости приемника пропускная способность снижается незначительно $<0.1 \%$. Уменьшение угла поля зрения фотодиода и половинного угла излучения существенно увеличивает пропускную способность (на 50\%) только при уменьшении до малых углов $\left(<10^{\circ}\right)$.

Выводы. Целесообразно фотодиода изготавливать из материала с большим показателем преломления, также не с малой площадью. Поскольку в офисной сети Li-Fi часто используются подвижные устройства, то не целесообразно в них уменьшать угол видимости приемника, как и уменьшать половинный угол излучения. Также может быть целесообразным давать подвижным пользователям большую пропускную способность загрузки, чем выгрузки.

Ключевые слова: Light-Fidelity (Li-Fi); пропускная способность; обратная связь; интервал обновления; VLC. 